\title{
Vascular endothelial growth factor genetic polymorphisms and susceptibility to age-related macular degeneration in Tunisian population
}

\author{
Imen Habibi', Imen Sfar', Fedra Kort ${ }^{2}$, Ahmed Chebil' ${ }^{2}$, Rim Bouraoui ${ }^{2}$, Rim Limaiem², Salwa Jendoubi-Ayed ${ }^{1}$, \\ Mouna Makhlouf', Taïeb Ben Abdallah', Khaled Ayed', Leila El Matri², Yousr Gorgi ${ }^{1 *}$
}

From 7th European Workshop on Immune-Mediated Inflammatory Diseases

Noordwijk aan Zee, the Netherlands. 28-30 November 2012

\section{Introduction}

Major genetics factors for age-related macular degeneration (AMD) have recently identified as susceptibility risk factors, underlying the role of the vascular endothelial growth factor (VEGF) system in AMD [1-4].

\footnotetext{
Aims

Our purpose was to determine whether (VEGF) gene polymorphisms play a role in either susceptibility risk for age-related macular degeneration (AMD) serum VEGF levels (s-VEGF) variations and treatment with intravitreal bevacizumab in Tunisians.
}

\section{Methods}

The case-control study included 157 patients with AMD and 207 age-matched controls. In all patients, ophthalmological examinations, visual acuity, optical coherence tomography (OCT), fundus photography and fluorescein angiography were performed. Sixty-two patients were treated with intravitreal bevacizumab. Single nucleotide polymorphism (SNP) genotyping (+936 C>T, +405 C>G and $-2578 \mathrm{~A}>\mathrm{G}$ ) were performed using direct sequencing. The serum VEGF was assayed by ELISA (R\&D).

\section{Results}

The single SNP +936 TT and +405 CC genotypes were significantly higher in AMD patients than in controls $\left(p=0.018\right.$ and $\mathrm{p}<10^{-3}$, respectively). Haplotype analysis of $\mathrm{SNP}+936,+405$ and -2578 revealed that TGA was associated to exudative form of disease $(\mathrm{p}<0.0001)$. However, single allele, genotype and haplotype association analyses

${ }^{1}$ Research Laboratory of Renal Transplantation and Immunopathology (LR03SP01), University Tunis El Manar, Charles Nicolle Hospital, Tunisia Full list of author information is available at the end of the article showed no significant association with s-VEGF levels variations, clinical forms of AMD or better outcome for distance and reading visual acuity after three bevacizumab injections.

\section{Conclusions}

Our results show that VEGF variants do contribute to the susceptibility to AMD in Tunisian patients. Further expression studies are needed to investigate the potential pharmacologic role of these variants in antiangiogenesis therapy.

\section{Author details}

${ }^{1}$ Research Laboratory of Renal Transplantation and Immunopathology (LR03SP01), University Tunis El Manar, Charles Nicolle Hospital, Tunisia. ${ }^{2}$ Oculogenetic Research Unit, Dept. B of Ophtalmology, Hedi Rais Institute of Ophthalmology, Tunis, Tunisia.

Published: 28 November 2012

\section{References}

1. Churchill AJ, Carter JG, Lovell HC: VEGF polymorphisms are associated with neovascular age-related macular degeneration. Human Molecular Genetics 2006, 15:2955-61.

2. Fang AM, Lee AY, Kulkarni M: Polymorphisms in the VEGFA and VEGFR-2 gene and neovascular age-related macular degeneration. Molecular Vision 2009, 15:2710-19.

3. Haines JL, Scbnetz-Boutaud N, Scbmidt S, Scott WK, Agarwal A, Postel EA, Olson L, Kenealy SJ, Hauser M, Gilbert JR, Pericak-Vance MA: Functional candidate genes in age-related macular degeneration: significant association with VEGF, VLDLR and LRP6. IOVS 2006, 47:329-335.

4. Penn JS, Madan A, Caldwell RB: Vascular endothelial growth factor in eye disease. Progress in Retinal and Eye Research 2008, 27:331-371.

\section{doi:10.1186/1479-5876-10-S3-P21}

Cite this article as: Habibi et al:: Vascular endothelial growth factor genetic polymorphisms and susceptibility to age-related macular degeneration in Tunisian population. Journal of Translational Medicine 2012 10(Suppl 3):P21. 